\title{
Editorial: Transition from Training to Practice-Is there a Better Way?
}

\author{
Seth S. Leopold MD
}

Received: 12 February 2014/ Accepted: 13 February 2014/Published online: 19 February 2014

(C) The Association of Bone and Joint Surgeons (R 2014

Approaches to resident and registrar education in the United States, United Kingdom, and elsewhere in Europe have changed dramatically in the last decade. Restrictions on duty hours, increased levels of supervision in the operating room required by government payers, and limitations on what trainees may do on their own in the clinic (again, generally motivated by billing obligations) are reasonable, they are here to stay, and they almost certainly have improved patient safety in training programs. Workweeks without limits and surgical training without supervision were bad for patients and for residents, and I am glad they are behind us.

Even so, we must recognize that shortening the duration of residency from more than 100 hours a week to less than 80, while also reducing clinical independence during training, could undermine preparedness. As such, we need to focus our attention on the transition from training to practice. We need to ensure that our efforts to make patient care safer during residency training have not made it less safe for patients who receive care from a surgeon who is fresh from training.

The author certifies that he, or any members of his immediate family, has no commercial associations (eg, consultancies, stock ownership, equity interest, patent/licensing arrangements, etc) that might pose a conflict of interest in connection with the submitted article.

All ICMJE Conflict of Interest Forms for authors and Clinical Orthopaedics and Related Research ${ }^{\mathbb{B}}$ editors and board members are on file with the publication and can be viewed on request.

The opinions expressed are those of the writers, and do not reflect the opinion or policy of $C O R R^{\circledR}$ or the Association of Bone and Joint Surgeons ${ }^{\circledR}$.

S. S. Leopold ( $\square)$

Clinical Orthopaedics and Related Research, Philadelphia, PA 19103, USA

e-mail: sleopold@ clinorthop.org
Good-faith efforts are being made to evaluate the preparedness of our residents [2], but high-quality data will never be available owing to the scarcity of objective standards defining when a surgeon is "ready" to practice. Astute observers have asked good questions about how well trained our graduates are, both in the United States [1] and in the United Kingdom [3]. These questions call for thoughtful responses.

I believe any answer should shift us away from the current binary model in which an individual a week before graduation is unfit and unable to see a patient unsupervised in the office, but the day after graduation can perform surgery of any level of complexity with little or no oversight. A better system would account for the variance of skills in each individual. A better system would account for the plain truth that skills vary widely from individual to individual, and that readiness comes at different times for different surgeons.

Ascertaining readiness of graduates for independent practice has implications for the graduates, their training programs, the practices that hire them, the specialty at large, and the public. All stakeholders should weigh in, but it seems clear to me that an important part of the answer must include a softening of the transition, a migration away from artificial dichotomies - that someone is either "in training" or else is "fully trained" - to one that that involves a semi-supervised period before the granting of full autonomy.

In one location, this already is being done. Dr. Oheneba Boachie-Adjei, a spine surgeon and winner of the American Academy of Orthopaedic Surgeons' Humanitarian Award, brings surgeons to a hospital in Ghana to do service work. He described to me how he maintains his urban high standards of quality and safety in this rustic environment by using his skills and experiences as a seasoned spinal 
deformity surgeon to grade planned surgical procedures that his center takes on using a 1 (mild procedure) to 5 (severe deformity procedure) scale. Level-5 operations may be performed only by a spine fellowship trained surgeon who has performed more than 100 deformity cases, including 25 of this level of difficulty under supervision.

No doubt you will have the same questions about this that I do: How will we know if this approach really is effective? Can this sort of grading be reproduced by others? How can this kind of system be put into play in settings where there are fewer surgeons available to do the grading and supervising? Although Dr. Boachie-Adjei has started to validate his approach, and others certainly have investigated how to evaluate surgical competency (the work of Van Heest et al. sets a high standard in this regard [4]), it is my impression that doing so rigorously and consistently will be difficult.

Closer to home, we are aware of practices that adopt similarly nurturing, well-supervised approaches to new hires. Some residencies have responded with programs that keep graduates on for an additional year of semi-supervised practice. Many of our graduates take fellowships. The oral board examinations represent a kind of supervision, in that some procedures performed by each candidate are reviewed in detail, but most are not. Even though this certification system is well intended, it has not evolved to keep pace with the changes in training that have shortened and constrained the experiences of a typical trainee.

We must recognize that many trainees do not perform surgery "solo" until late in training (if even then), and that completely nurturing environments remain the exception, not the rule. Working against the desired result includes the financial incentives of practices and new graduates, the new-graduates' professional desires to practice independently, and senior partners' time demands.

Therefore, how can we provide a transition from training into practice that does not leave young surgeons vulnerable to failures that can harm their confidence, their development, and their patients?

Please share your thoughts as a Letter to the Editor, which you can send to me at eic@clinorthop.org.

Acknowledgments I would like to thank Joseph Bernstein MD, Paul J. Dougherty MD, and Lee Beadling BS, for sharing their expertise on this topic and for the many critical suggestions that informed and improved this essay. I am especially indebted to Oheneba Boachie-Adjei MD for sharing his innovative and thoughtful approach with me. Finally, I would like to thank Frederick A. Matsen III MD, who made me aware of Dr. Boachie-Adjei's program, who started the conversation that lead to this essay, and whose generous mentorship has contributed immeasurably to my own professional development.

\section{References}

1. Chen PW. Are today's new surgeons unprepared. Available at: http://well.blogs.nytimes.com/2013/12/12/are-todays-new-surgeonsunprepared/?_php=true \&_type=blogs \&_php=true \&_type=blogs \&_ $\mathrm{r}=2$. Accessed February 10, 2014.

2. Dougherty PJ. What the ACGME's next accreditation system means to you. Clin Orthop Relat Res.2013;471:2746-2750.

3. Ferguson H, Fitzgerald E, Shalhoub J, Gokani V, Beamish A. The shape of training: Review 2013. A response on behalf of the Council of the Association of Surgeons in Training. Available at: http://www.asit.org/assets/documents/ShoT20Response20Final20 Draft.pdf, Accessed January 6, 2014.

4. Van Heest A, Putnam M, Agel J, Shanedling J, McPherson S, Schmitz C. Assessment of technical skills of orthopaedic surgery residents performing open carpal tunnel release surgery. $J$ Bone Joint Surg Am. 2009;91:2811-2817. 